\title{
生産性追求は環境保全と相容れないのか
}

一環境保全型農業への移行に向けた理論視座の確立を求めて一

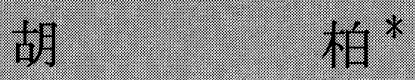

\section{Is the Pursuit of Improving Agricultural Productivity Incompatible with the Effort of Transition to Sustainable Farming System?}

\author{
Hu Bai (Ehime University)
}

\begin{abstract}
Increasing interest in agricultural environmental issues seems to be leading to the decline of concern for agricultural productivity. Parting from the pursuit of agricultural productivity is regarded as an essential of transition to a sustainable farming system (SFS) among some of journalists and even the researchers in the field of agricultural economics.

This paper critically examines this view. The main conclusions are as follows. The agricultural policy since the Agricultural Basic Law (1961) has paid special attention to the labor saving-biased efficiency standard, in response to labor shortage in agriculture, whereas it
\end{abstract}

neglected the improvement in overall productivity of industrial input and natural resources. The labor savingbiased farming system, featuring the substitution of fuel energy and agricultural chemicals for farm labor, has caused a decline in economic efficiency of agricultural industry, not to mention a rise in environmental deterioration. The transition to a SFS therefore calls for improved and efficient use of industrial input and natural resources, or agricultural productivity. To simultaneously achieve economic and environmental benefits from farming activities, it is necessary to shift away from the labor savingbiased efficiency standard to total factor productivity.

\section{1. はじめに}

農業環境問題に関する論議において,「生産性」 （あるいは「効率性」）と「環境」を対立コンセプト として捉える向きがある. 今クローズアップされて いる農業環境問題の多くは, 戦後農政が進めてきた 近代農法の結果であり, 生産性あるいは効率性 ${ }^{1)}$ へ の追求が近代農法の最たる特徵と見なされているか らである. したがって, 持続的で環境保全を重視す る農業への移行 ${ }^{2)}$ を図るためには, 生産 (効率) 性 重視の農政と決別しなければならず, 生産性追求農 法への決別こそ, 農法転換の条件だと見るのである.

このような考えは, マスコミや近代農法批判論者 のみならず, 農業経営経済学界においても影響力を

\footnotetext{
*愛媛大学農学部
}

増している.この種の記事は枚挙にいとまがないが, 例えば, 長期にわたって農業経済学界をリードし, 重厚な理論成果 ${ }^{3)}$ を提供し続けてきた梶井功教授 すら，その著書において「本来は環境保全産業であ るはずの農業が, 生産性追求農法の結果, 環境への 負荷を増大させる産業になってしまっている」との 認識を示し,「こうした生産性追求農法は, これか らも是認されるべきか」と問い掛けている ${ }^{4)}$. 同様 の論点は, 2004 年度日本有機農業学会においても提 起されている5).

そして，こうした認識は農業政策の形成にも影響 を及ぼしつつある，農政側の見解を示す『食料・農 業・農村白書 (平成 15 年度版)』に打いては, 「効 率性を重視してきたこともあり，農業生産に打ける 環境に対する負荷の増大への懸念が高まっている」 （p.190）と指摘する. 環境保全型農業への直接支払 
いを検討している食料・農業・農村政策審議会企画 部会の最近の検討作業において，直接支払い制度を 導入する際に「零細な農業構造を温存しないことに 留意」し,「生産性向上と環境保全を両立させる「日 本型」施策の創設を目指す」考えがある一方，「効 率的な農業と環境保全を両立させることに疑問」視 する意見も出されている ${ }^{6)}$. 意見の相違は言うまで もなく, 生産性と環境との関係に対する基本的認識 に由来するものがあり，今後の政策形成に何らかの 影響を与えることも当然考えられる。

生産性追求は環境保全と相容れないのか.この問 題は, 近代農法への反省や 21 世紀に相応しい「食」 と「農」の形づくりを考える上でも極めて重要な意 味を有すると思われるだけに，明確にしておく必要 がある. マスコミや学界では, 環境問題への関心の 高まりにつれて生産性向上，効率改善を主張する自 信が摇らいでいるのとは対照的に, 環境保全型農業 に取り組む有機認証農家やエコファーマーの多く は，農法転換に伴う生産りスクの増大，労働時間・ 費用の増加等の悩みを抱え, 収量安定や収益向上に 結び付く経営手法の確立に向けて懸命な努力を続け ている. 環境保全型農業の普及・定着を図るために も, 生産性と環境との関係についての検討が必要不 可欠であると考える.

本稿では, 論点提起のつもりで課題をこの一点に 絞る。第 2 節では，これまでの農政における「生産 性向上」とは何だったのかを明らかにする．第 3 節 では, この種の「生産性」尺度は如何に構造的な欠 陥を有し，こうした「生産性向上」への追求が如何 に非効率性を生み, 丕んだ生産性認識を醸成したか を検証する，第 4 節では，生産性と環境を統合した 農業経営の動きを示し，その理論的，実践的意味を 吟味する。第 5 節では, 健全な生産性基準の確立に 向けて努力すべき課題を提示する.

\section{2.これまでの農政において，生産性の向上とは 何だったのか}

周知のように, 生産性の向上は基本法農政期の農 業政策を特徵付ける1つのキーワードであった. 1961 年に制定された「農業基本法」の中では, 国の農業 に関する政策の目標を「他産業との生産性格差が是 正されるように農業の生産性が向上すること及び農 業従事者が所得を増大して他産業従事者と均衡する
生活を営むことを期することができることを目途と して, 農業の発展と農業従事者の地位の向上を図る ことにあるもの」（第 1 章第 1 条）とし，この政策 目標が毎年どこまで, どのように達成されたかを把 握するため, 「政府は, 毎年, 国会に, 農業の動向 及び政府が農業に関して講じた施策に関する報告を 提出しなければならない」(第 6 条第 1 項)こと, そ の「報告には, 農業の生産性及び農業従事者の生活 水準の動向並びにこれらについての政府の所見が含 まれていなければならない」(同，第 2 項）ことを 定めている.

つまり,生産性の向上は基本法農政の目標であり, 手段であり，政策遂行の実績を評価する尺度でも あったのである. 農業の生産性向上が重視された背 景は, 「近時, 経済の著しい発展に伴なって農業と 他産業との間において生産性及び従事者の生活水準 の格差が拡大しつつ」, 一,「また, 他産業への労働 力の移動の現象が見られる」こと（同法，前書き） にあった，他産業との生産性抢よび所得水準格差の 拡大, または他産業への労働力移動から生じてこよ うと予想される農業労働力不足への対応を強く意識 した同法律は, 農業の労働生産性の向上を特に重要 視していた。この点は, 国会に提出される毎年の 「農業の動向に関する年次報告」(農業白書) の一節 となる「農業の生産性と農家の生活水準」の指標構 成をみれば明白である。そこに農業と製造業の「物 的労働生産性指数」, および農業と製造業, 非農業 部門の「就業者 1 人当たり純生産」が比較され, 農 業基本法に書か机ている「農業の生産性」は農業の 労㗢生産性の形で具体的に示されたのである.

労働生産性の向上は, その後, 農業機械化・施設 化の進展および農業外部投入財の増大に象徴される 「体化された技術進歩」によって大きな成果を収め ることができた. 表 1 は, 1960 年以降に打ける農業 労働生産性の動きを示したものである7 ${ }^{7} .1960 ９ 0$ 年期間において土地生産性は 2 倍上昇し, $10 \mathrm{a}$ 当た り労働時間が逆に半減したため, 労働生産性は 4 倍 も上昇した，これを年率に換算すると，期間を通し て年 $4.7 \%$ に上る高い伸び率となる. $1960 \sim 75$ 年 期間に限ってみると，伸び率は $7.1 \%$ にも達する. 他方では，農機具や資材の投入が実質生産額の伸び を上回る速さで増大したため, 資本の生産性が急速 に低下してきた。 
表 1. $10 \mathrm{a}$ 当たり農業の投入と産出

単位: 数量指数 $\%$

\begin{tabular}{|c|c|c|c|c|c|c|c|c|}
\hline \multirow{3}{*}{ 年次 } & \multirow{3}{*}{$\begin{array}{c}\text { 実質生産額 } \\
\text { (1) }\end{array}$} & \multirow{3}{*}{$\begin{array}{c}\text { 労働時間 } \\
\text { (2) }\end{array}$} & \multicolumn{3}{|c|}{ 実質物財費 } & \multirow{3}{*}{$\begin{array}{c}\text { 労働生産性 } \\
\text { (1) / (2) }\end{array}$} & \multirow{3}{*}{$\begin{array}{c}\text { 資本生産性（1） } \\
\text { (1) / (3) }\end{array}$} & \multirow{3}{*}{$\begin{array}{c}\text { 資本生産性（2） } \\
\text { (1) / (5) }\end{array}$} \\
\hline & & & 計 & 経常財 & 農機具 & & & \\
\hline & & & (3) & (4) & (5) & & & \\
\hline 1960 & 100 & 100 & 100 & 100 & 100 & 100 & 100 & 100 \\
\hline 65 & 129 & 83 & 195 & 197 & 234 & 155 & 66 & 55 \\
\hline 70 & 163 & 81 & 329 & 328 & 443 & 202 & 49 & 37 \\
\hline 75 & 197 & 70 & 370 & 374 & 542 & 280 & 53 & 36 \\
\hline 80 & 180 & 58 & 459 & 431 & 752 & 309 & 39 & 24 \\
\hline 85 & 195 & 54 & 525 & 475 & 883 & 362 & 37 & 22 \\
\hline 90 & 200 & 50 & 540 & 510 & 871 & 397 & 37 & 23 \\
\hline
\end{tabular}

註 : 農林水産省「農家経済調査」(都府県) および「農村物価統計」により算出. 1992 年から集計対象農家が販売農家だ けとなり, かつ農家 1 戸当たり経営耕地面積が 1991 年の 107.8 a から 133.6 a へと $24 \%$ 増大したため, 集計対象農 家の「質」が変わったと認識し，計算期間を 1990 年までとした.

土地利用型農業の象徴である稲作においても同様 の傾向が示されている. 1960 から 95 年にかけての 35 年間に扔いて, 米の単収は $20 \%$ 伸びたのに対し て, 労働生産性は 5.3 倍も上昇した。同期間におい て資本や経常財による労働への代替が急速に進み, $10 \mathrm{a}$ 当たり労働時間数が 8 割も減少したからであ る.これを年率に換算すると $4.9 \%$ の伸び率となり， 表 1 に示す農業部門全体のそれを上回る.

農業における労働生産性の飛躍的な向上は, 農業 基本法が目指した他産業との生産性及び生活水準の 格差の解消には至らなかったが, 重要な意味があっ た.これが, 速水の国際比較により明示されている. 氏の計算によれば， $1960 ８ 0$ 年において先進諸国 における農業労働生産性の伸び率は, 米国は 6. 3\%, 英国は $5.5 \%$ ，フランスは $6.4 \%$ ，西ドイツは $7.7 \%$ であったのに対し, 韓国, フィリピン, インドでは, それぞれ $4.0 \%, 3.2 \%, 1.3 \%$ であった ${ }^{8)}$. これに 比べて, 同期間に扔ける日本農業の労㗢生産性の伸

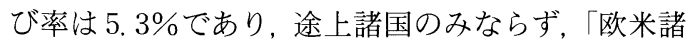
国のそれに比べてほとんど遜色がない」9）もので あった。

農林水産省は, $1960 \sim 94$ 年を対象期間に同様の 試算を行ったことがあるが, 速水とほぼ同様の結論 を得たそそれによると, 試算期間において日本農業 の物的労働生産性の上昇率は年 $4.8 \%$ であった。 こ れに比べて，欧米農業先進諸国のそれ（1960～93 年期間）が, 米国は 3.0\%, 英国は 3.5\%, フラン スは $5.6 \%$, 西ドイツは $3.6 \%$ であった ${ }^{10)}$ 。日本農
業は, フランスを除く欧米諸国を上回る労働生産性 の向上を達成したのである.

これらの比較は，いずれも「就業者 1 人当たり純 生産」でなく，「物的労働生産性指数」を使ってい るが，「新しい食料・農業・農村政策の方向」（略称 「新政策」）においては,「戦後, 我が国経済社会は 効率性と「物の豊かさ」を追求しながら発展してき た. その過程で, 農業及び農村は国民経済の発展と 国民生活の向上に深く係わってきた。 そして, 農業 の生産性は欧米に比べても決して遜色ない伸びを示 した.」（I 政策展開の考え方, 傍点は著者追加）と の評価を示している. また，1960～94 年期間の試 算結果を引用した平成 8 年度『農業白書』において も，「決して低くない我が国農業の生産性の上昇率」 「我が国農業と諸外国の農業とを比較してもそん色 のない生産性の向上を達成してきている」（p. 106） と解説している。

農家経済や農業経営のパフォーマンスを示す生産 性指標として,「農業経営動向統計」(1994 年までは 「農家経済調査」)に打いては農業純生産べースの土 地生産性, 固定資本生産性も算出されている. しか し以上に示したように, 農政用語として使われてい る「農業の生産性」とは, ほとんどの場合, 農業の 物的労働生産性のみを指している。言い換えれば, 農業政策に打ける「生産性の向上」とは, 農業の労 働生産性の向上, より正確に言えば，農業に打ける 物的労働生産性向上と同義語であったのである. 


\section{3. 労働生産性の吟味}

欧米農業先進諸国に比べて農地規模が零細分散 し， 7 割の農家が農業以外の仕事を主業とする構造 の中で，国民の主食に対する需要を満たすに足りる 土地生産性を上げるとともに，欧米農業先進諸国に 比べて遜色のない物的労働生産性の向上を実現した ことは，戦後農業の大きな成果と言える，従前，農 業労働者を田戋や畑仕事に縛り付け, 多くの労働時 間を要していた農作業は, 労働生産性の飛躍的向上 によってよりまとまった少ない時間でこなすことが 可能となり，重労動から解放されたからである。 こ の重労働からの解放というかつてない農業生産力の 進歩過程が零細錯圃的な農業構造の下で成し遂げら れたことは，特筆に值するものと言って過言ではな い.

問題は，労働生産性のみを重視し，基本法がいう 「農業の生産性」の向上を労働生産性の向上に置き 換え, 物的労働生産性のみが追求され続けてきた点 である. 後に示すように, このことは, 農業環境問 題が生産性追求の結果だという誤解を招いた最大の 理由である.

周知のように, 労働生産性は生産物 (Y) 対労働投 入（L）の比率関係を表すものである，その変化率 は, 同比率関係で示寸生産物と労働時間との一対一 の関係のみに規定されるのでなく，農地（A）や資 本 $(\mathrm{K})$ との結合関係，単位面積当たり資本投入量 あるいは資本集約度 $(\mathrm{K} / \mathrm{A})$ ，および資本生産性 $(\mathrm{Y} /$ K）の変化にも依存する. 変化率を $\mathrm{G}(\cdot)$ で表すと, 労 働生産性の変化率 $\mathrm{G}(\mathrm{Y} / \mathrm{L})$ は以下のように分解する ことができる.

$$
\mathrm{G}(\mathrm{Y} / \mathrm{L})=\mathrm{G}(\mathrm{A} / \mathrm{L})+\mathrm{G}(\mathrm{K} / \mathrm{A})+\mathrm{G}(\mathrm{Y} / \mathrm{K})
$$

この式から明らかなように, 要素利用効率の改善 は労働生産性の向上に寄与するが, 必要条件ではな い. 資本生産性の上昇がなくても, 労働生産性の向 上は農地面積対労働比率 $(\mathrm{A} / \mathrm{L})$ や資本集約度の上 昇によって達成可能だからである。 この式を用いて $1960 \sim 90$ 年期間における農業労働生産性の变化率 を分解した結果は，表 2 に示す，農業部門全体の場 合, 年 $4.7 \%$ に上る労働生産性上昇のうち, 作付面 積対労働比率変化の寄与は $46.4 \%$, 資本集約度の寄 与は $123.0 \%$, 資本生産性の寄与は $-69.4 \%$ となっ
表 2. 農業の労働生産性変化の要因分解

\begin{tabular}{lrrrr} 
& & & \multicolumn{3}{r}{ 単位 : \% } \\
\hline \hline \multirow{2}{*}{ 区 分 } & 労働生産性 & \multicolumn{3}{c}{ 要因分解 } \\
\cline { 3 - 6 } & $\mathrm{Y} / \mathrm{L}$ & $(\mathrm{A} / \mathrm{L})$ & $(\mathrm{K} / \mathrm{A})$ & $(\mathrm{Y} / \mathrm{K})$ \\
\hline 農業 & & & & \\
$\quad$ 堌減年率 & 4.7 & 2.2 & 5.8 & -3.3 \\
$\quad$ 奇与率 & 100.0 & 46.4 & 123.0 & -69.4 \\
稲作 & & & & \\
$\quad$ 増減年率 & 4.9 & 4.3 & 3.2 & -2.6 \\
$\quad$ 寄与率 & 100.0 & 87.4 & 65.5 & -52.9 \\
\hline
\end{tabular}

註：1）農業全体は第 1 表の変化率, 稲作は「米生産費調 査」により算出． A， L， K はそれぞれ作付面積, 労働時間，および資本を表す。

2）資本 $\mathrm{K}$ は，実質物財費の集計値を使っている.

ており, 資本集約度の上昇は労働生産性の向上に最 も寄与している，稲作のみの場合，最大の寄与を示 したのは作付面積対労働比率の変化で, 資本集約度 変化の寄与はその次である. 資本生産性変化の寄与 は，農業部門全体と同様にマイナスとなっている.

作付面積対労働比率変化の寄与は, 規模拡大ある いは構造改善の効果を表していると思われがちだ が，実態はそうでない，考察期間においてサンプル 農家の1戸当たり作付面積がほとんど拡大しておら ず, (A/L) 変化の寄与は, 労働時間節約の寄与を示 したものに他ならない. 労働時間の節約は農業機械 化・施設化の進展並びにそれに伴う資本サービスの 向上, および化学肥料や除草剂等資材の使用が大き く貢献していることから, (A/L) 変化の寄与は, 資 本集約度（K/A）の向上に伴って生まれた一種の派 生効果と見てよいであろう。つまり, 1960 年代以降 における農業労働生産性の著しい上昇は, 主として 単位面積当たり資本材投入の増大およびそれに伴っ て派生する労働時間の大幅な節約によってもたらさ れたものであり, その過程で資本の生産性が急速に 低下したのである（表 1).

労働生産性は, 土地生産性や資本生産性等部分的 要素の生産性指標と同じように, 他の生産要素の貢 献を捨象して割り出した比率であり, 統計学上ある いは経済学的意味において構造的な欠陥を持ってい る. 生産物 $\mathrm{Y}$ は, 労働力と資本（広義的には物的投 入財）および土地との結合によって形成される労働 過程の結果だから，その価値構成は労働投入の貢献 分 $\left(\mathrm{Y}_{\mathrm{L}}\right)$ だけでなく, 資本 $\mathrm{K}$ の貢献分 $\left(\mathrm{Y}_{\mathrm{K}}\right)$, 農地 
$\mathrm{A}$ の貢献分 $\left(\mathrm{Y}_{\mathrm{A}}\right)$ も当然含まれる。つまり, $\mathrm{Y}=\mathrm{Y}_{\mathrm{L}}+$ $\mathrm{Y}_{\mathrm{K}}+\mathrm{Y}_{\mathrm{A}}$ である.これを労働時間で割り通常の労働生 産性を計算すると,

$$
\begin{aligned}
(\mathrm{Y} / \mathrm{L}) & =\left(\mathrm{Y}_{\mathrm{L}}+\mathrm{Y}_{\mathrm{K}}+\mathrm{Y}_{\mathrm{A}}\right) / \mathrm{L} \\
& =\left(\mathrm{Y}_{\mathrm{I}} / \mathrm{L}\right)+\left(\mathrm{Y}_{\mathrm{K}}+\mathrm{Y}_{\mathrm{A}}\right) / \mathrm{L} 1 \\
& =\text { 正味の労働生産性十見せかけの労働生産性 }
\end{aligned}
$$

になる.（2）式右辺の第 1 項は, 労働投入の産出貢 献分 $\left(\mathrm{Y}_{\mathrm{L}}\right)$ を労働投入量 $(\mathrm{L})$ で除したもので, 労 働の効率あるいは正味の労働生産性を表しているの に対し，第 2 項は，労働以外投入財や農地の産出貢 献分 $\left(\mathrm{Y}_{\mathrm{K}}+\mathrm{Y}_{\mathrm{A}}\right)$ と労働投入 (L) という全く異質的 な要素の組み合わせにより算出された比率であり, 見せかけの労働効率として通常の労働生産性の計算 に加わっている。一般的に使われている労働生産性 $(\mathrm{Y} / \mathrm{L})$ に資本 $\mathrm{K}$ と農地 $\mathrm{A}$ の貢献分に相当する「見 せかけの労働生産性」，つまり $\left[\left(\mathrm{Y}_{\mathrm{K}}+\mathrm{Y}_{\mathrm{A}}\right) / \mathrm{L}\right]$ が含 まれるため, 労働の生産性パフォーマンスはつ㱛に 過大評価される. 労働生産性を高めるために投入さ れた資本 $\mathrm{K}$ と農地 $\mathrm{A}$ の費用をも勘定に取り入れ,つ まり，生産物 $\mathrm{Y}$ から労㗢以外投入 $\mathrm{K}$ と A の貢献分 $\left(\mathrm{Y}_{\mathrm{K}}+\mathrm{Y}_{\mathrm{A}}\right)$ を除いて正味の労㗢生産性 $\left(\mathrm{Y}_{\mathrm{L}} \mathrm{L}\right)$ のみ を計算すれば, 労働の生産性パフォーマンスがかな りデイスカウントされるはずである.

（2）式で示した正味の労㗢生産性と通常の物的労 働生産性との違いを試算してみよう。 J.B. クラーク とウィックステイードの生産物完全分配定理によれ ば, 生産物 $\mathrm{Y}$ における $\mathrm{K}, \mathrm{A}$ の寄与分 $\mathrm{Y}_{\mathrm{K}}$ と $\mathrm{Y}_{\mathrm{A}}$ はそ
れぞれの費用 $\mathrm{C}_{\mathrm{K}}, \mathrm{C}_{\mathrm{A}}$ に等しくなり, 従って, 労働 $\mathrm{L}$ の貢献分, つまり競争的帰属価値 $\mathrm{Y}_{\mathrm{L}}$ は $\left(\mathrm{Y}_{\mathrm{L}}=\mathrm{Y}-\mathrm{Y}_{\mathrm{K}^{-}}\right.$ $\left.\mathrm{Y}_{\mathrm{A}} \equiv \mathrm{Y}-\mathrm{C}_{\mathrm{K}}-\mathrm{C}_{\mathrm{A}}\right)$ により算出される ${ }^{11)}$. これを労働 時間 $\mathrm{L}$ で割ると（ $\mathrm{Y}_{\mathrm{L}} / \mathrm{L} ）$ の名目値，さらに農村消費 者物価指数で除すると, その実質的变化を見ること もできる.

試算結果は表 3 に示す. 正味の労働生産性 $\left(\mathrm{Y}_{\mathrm{I}}\right)$ L）は，(7)の名目值と(9)の実質值で表示されている. 1975 年までは 1960 年の值が極端に低かったことも あって，名目值も実質值も飛躍的に上昇したが，そ の後の $1975 \sim 90$ 年期間では, 名目値は期間を通し て $30 \%$, 年率にしては $1.7 \%$ 強の伸び率となり, 通 常の物的労働生産性の伸び率（実質年率 $2.4 \%$ ，表 1）を $1 / 3$ 程下回る。 さらに，これを農村消費者物 価指数で除し得られた実質值の変化傾向を見ると, 1975 年まで年 $6.6 \%$ 高い伸び率であったが，その 後は低下に転じ， 75 年水準まで回復することはな かった（2）式に照らして言うならば，表 1 に算出 されたこの期間の物的労働生産性の上昇率（年 2.4 \%）は，主として K と A の貢献分に相当する「見 せかけの労働生産性」の伸びによるものであり，こ れを除けば生産性の上昇はなかった，ということに なる.

生産性の停滞をもたらした要因は，同表(10欄の経 営費対粗収益比率により明快に示されている。考察 期間において土地生産性の伸びを上回るぺースで機 械設備や資材が投入されたため(表 1)，農業粗收益

\begin{tabular}{|c|c|c|c|c|c|c|c|c|c|c|c|}
\hline 項 目 & 単 位 & 計算番号 & 1960 & 65 & 70 & 75 & 80 & 85 & 90 & 95 & 2000 \\
\hline 10 a 当たり粗収益 & 千円 & (1) & 27.5 & 56.8 & 94.3 & 204.3 & 225.9 & 252.0 & 264.8 & 269. 6 & 240.9 \\
\hline 10 a 当たり経営費 & 千円 & (2) & 10.4 & 24.3 & 45. 3 & 90.7 & 136.0 & 157.7 & 160.8 & 164.9 & 164.2 \\
\hline 10 a 当たり農地関連費用 & $" 1$ & (3) & 0.4 & 0.7 & 1.5 & 3. 3 & 5. 0 & 7.1 & 9. 3 & 10.0 & 9.2 \\
\hline $10 \mathrm{a}$ 当たり物的投入財 & 11 & (4) & 9.5 & 22.7 & 42.6 & 85.6 & 129.0 & 147.9 & 148.5 & 150.4 & 150.0 \\
\hline 10 a 当たり労働帰属価值 & 11 & (5) $=$ (1) - (3) - (4) & 17. 6 & 33.3 & 50.2 & 115.4 & 91.9 & 96.9 & 107.0 & 109. 2 & 81.7 \\
\hline 10 a 当たり 農業労働時間 & 時間数 & (6) & 288 & 240 & 232 & 203 & 168 & 155 & 145 & 128 & 124 \\
\hline 正味の農業労働生産性 : 名目値 & 円/時間 & (7) $=$ (5) $/$ (6) $* 1000$ & 61 & 139 & 217 & 569 & 548 & 625 & 738 & 855 & 660 \\
\hline 農村消費者物価指数 & $\%$ & (8) & 17. 4 & 27. 9 & 35.8 & 61.6 & 83. 8 & 91.7 & 96.9 & 100.0 & 101. 0 \\
\hline 正味の農業労働生産性 : 実質値 & & (9) $=(7) /(8) * 100$ & 353 & 499 & 606 & 924 & 653 & 681 & 761 & 855 & 653 \\
\hline 経営費 / 粗収益比率 & $\%$ & (10) $=$ (2) $/$ (1) $* 100$ & 37.6 & 42.8 & 48. 1 & 44. 4 & 60.2 & 62.6 & 60.7 & 61.2 & 68.2 \\
\hline
\end{tabular}
に占める経営費の割合は 1960 年の 3 割台から, 70

表 3. 農業における正味の労働生産性の試算

註 : 1) 農業労働時間は男女賃金率比で計算された男子相当労働時間である.

2） 1992 年以前とその後の集計対象農家や経営費項目の相違から生じた生産性格差は調整していない，

3）農地関連費用に土地改良費・水利費，および支払小作料を含む.

4）その他は第 1 表を参照されたい. 
年代の 4 割台, 80 年代以降の 6 割台へと上昇してき た.その結果, 通常でいう物的学働生産性が上昇し てきたものの，1 単位の総合投入に対する産出の割 合が急速に低下し，投入の総合効率，言い換えれば, 本来意味上の農業の生産性が悪化してきたのであ る.

このように, これまでの農法は, よく言われてい る「生産性追求農法」でもなければ, 「効率性追求 農法」でもなく, 労働の生産性のみ, 正確に言えば, 物的労働生産性を物差とした省力化追求農法であっ た.こうした農法体系の中で, 農業の生産性は物的 労働生産性のみにより評価され, 労働以外物的資源 （資本，経常財等）の効率性, 生産性が無視された. その結果, 通常の労働生産性が目覚ましい上昇を遂 げたが，資材の過剩な投入で労働以外資源の生産性 が急速に低下したため, 本来意味の「農業の生産性」 あるいは農業の総合経済効率がむしろ悪化した。労 働生産性本位の省力化追求農法は著しい非効率性を 生み, 生産性追求農法ではなかったのである.

そして, 省力化を特徴とする物的労働生産性の追 求は, 農政用語において「農業の生産性」の向上と 同等に使われてきたため, 丕んだ生産性認識を醸成 し, 生産性追求が環境への負荷を増大させる誤解を 招いた。

\section{4. 生産性追求と環境保全との調和：証拠と意味}

環境に負荷を与える農業部門の主な経営活動とし て, 平成 11 年度「食料・農業・農村の動向に関す る年次報告」では，「化学肥料・農薬の不適切な使 用」（p. 255）「有機性廃棄物」「農業用使用済みプラ スチック等農業生産資材」の不適切な処理 (p. 268), 「農業機械や施設での化石燃料等の使用」增大 (p. 270）などを挙げている．関連する投入財の使用増 大は, 作物の収量向上と安定, 農業労働の省力化等 のために行われてきたが, 70 年代以降における農産 物過利の深刻化, 減反政策の実施に伴って収量向上 の側面が後退し, 省力化すなわち労働生産性の向上 がより重視されるようになった、「農業の生産性」を 「物的労働生産性」だけでなく，労働以外資源の利 用効率をも考慮した農業経営活動全般の生産性とし て捉えるならば, 生産性追求が環境への負荷を増大 させるとの見方は成り立たなくなる.

生産性, 効率性に優れた農業経営と言えば, 大規
模経営や法人経営がまず挙げられよう. 生産性追求 が環境への負荷を増大させる結果をもたらすなら ば，小規模経営よりも，「効率感覚に優れた」大規 模経営や法人経営の方が環境に負荷を与えるような 農法をより多く取り入れ，環境保全型農法の導入に 消極的になろう。しかしこれは, 農業経営の実態に 符合するものではない. 表 4 は, 米の生産費調査に 基づいて算出した，玄米 1 俵当たり環境関連資材費 （農薬, 肥料, 光熱動力費）を示している ${ }^{12)}$. 光熱 動力費については, どの時期も傾向的な階層性が見 られず，農薬と肥料費については，3つの時期とも 規模が大きくなるにつれて低下する傾向が示されて いる. 1999-2001 年期間を例にしてみると， 5 ha 以 上層では，米 1 俵を作るために所要する農薬，肥料 の費用がそれぞれ 715 円，823 円であるのに対し， 0.5 ha 以下層のそれがそれぞれ 945 円, 1, 088 円で, 前者より 2 割も高い. 規模の大きい経営ほど, 環境 関連資材の使用が相対的に節約的である.

図表は省略するが，米作に似たような傾向が 80 年代以降の農家経営統計調査においても示されてい る. 例えば，1989-91 年期間おいて規模の大きい経 営層ほど粗収益 1000 円当たり農薬, 肥料費が少な い傾向がある. 1999-2001 年期間になると, 畜産農 家のサンプル数が多かった 0.5 ha 以下層を除けば, 農薬, 肥料, 光熱動力費とも同様の傾向となってい る. 同一単位の富（生産額）を創出するために所要 する環境関連資材費は大規模経営ほど安く, 言い換 えれば, 経営規模の大きい農家層ほど, 環境への負 荷が相対的に小さいのである.

そして表 4 の備考闌では，規模の増大につれて米 1俵当たり生産費総額も低下する傾向を示している. 経営規模の大きい農家層ほど, 資源利用の効率性が よく生産性が高いのである。これを環境関連資材費 の規模階層別傾向と付き合わせると, 効率的で生産 性の高い経営ほど環境への負荷が相対的に少ない, という結論に辿りつくであろう.

効率的で生産性の高い農業経営ほど, 環境への負 荷が相対的に少ないということだけでも，農業経営 と環境との関係を考える上で多くの示唆を与えてく れると思うが, より重要で新しい事実がある. 効率 的で生産性の高い農業経営の方が, 環境保全型農法 の導入にも積極的である，ということである.

2000 年農業センサスによれば, 環境保全型農業へ 
表 4. 経営規模別米 $60 \mathrm{~kg}$ 当たり環境関連資材費（都府県）

\begin{tabular}{|c|c|c|c|c|c|c|c|}
\hline 年度 & $<0.5$ ha & $0.5-1.0$ & 1. $0-1.5$ & 1. 5-2.0 & 2. $0-3.0$ & 3. $0-5.0$ & $>5.0$ ha \\
\hline \multicolumn{8}{|c|}{ 1999-01 年平均 } \\
\hline 農薬費 & 945 & 927 & 851 & 845 & 819 & 746 & 715 \\
\hline 肥料費 & 1,088 & 971 & 923 & 869 & 853 & 809 & 823 \\
\hline 光熱動力費 & 351 & 344 & 336 & 344 & 328 & 313 & 325 \\
\hline \multicolumn{8}{|c|}{ 1989-91 年平均 } \\
\hline 農薬費 & 976 & 933 & 865 & 820 & 845 & 787 & 817 \\
\hline 肥料費 & 1,188 & 1,110 & 1,036 & 961 & 1,064 & 954 & 1,105 \\
\hline 光熱動力費 & 358 & 369 & 374 & 379 & 361 & 346 & 364 \\
\hline \multicolumn{8}{|c|}{ 1979-81 年平均 } \\
\hline 農薬費 & 811 & 747 & 748 & 766 & 714 & 636 & - \\
\hline 肥料費 & 1,266 & 1,225 & 1,148 & 1,132 & 1,157 & 1,051 & - \\
\hline 光熱動力費 & 402 & 437 & 438 & 438 & 449 & 443 & - \\
\hline \multicolumn{8}{|c|}{ 備考：生産費総額 } \\
\hline 1999-01 & 21,270 & 17,712 & 15,297 & 14,007 & 12,939 & 11,848 & 11,008 \\
\hline $1989-91$ & 20,824 & 18,315 & 15,430 & 14,072 & 13,215 & 12,200 & 11,550 \\
\hline $1979-81$ & 19,256 & 16,207 & 14,071 & 12,649 & 11,561 & 9, 963 & 8,854 \\
\hline
\end{tabular}

註 : 1)「米生産費調査」により作成

2）「生産費総額」とは, 1990 年までは第 1 次生産費, その後は支払利子・地代算入生産費の額である.

3） 1991 年前の $<0.5$ ha 層の值は $<0.3$ ha 層と 0. 3-0.5 ha 層の単純平均值である.

の取組は 50 万 4,000 経営体あり, 約 234 万農業経 営体の $21.5 \%$ 占为る ${ }^{13)}$. 経営形態別には, 通常 の家族経営は $21.4 \%$ でるのに対して, 家族法人は $44.2 \%$, 農家以外の農業事業体は $30.7 \%$ となってい る. 効率感覚に優れた法人, 会社経営の方が環境保 全型農業への取組は多い.

これをさらに栽培形態別に分けてみると,「無農 薬」「無化学肥料」栽培において家族経営はそれぞ れ $1.1 \%, 1.4 \%$ あるるのに対して, 家族法人経営は $4.7 \%, 6.0 \%$, 農家以外農業事業体は $5.3 \%, 5.1 \%$ で，家族経営より数倍も高い值を示している．「減 農薬」「減化学肥料」栽培についても, 家族法人経 営体は断卜ツ高い数值で家族経営を引き離してい る。つまり, 取組経営体平均においてのみならず, 農薬の使用回数, 化学肥料の使用量を 5 割以上削減, あるいは全く使用しない比較的高い水準の取組にお いても, 家族法人経営, 農家以外の法人・会社経営 の方が家族経営より進んでいるのである.

規模階層別傾向を示したのが，表 5 である. 販売 目的で米を作っている米作農家のみのデータである
が，野菜，果樹栽培農家も似たような傾向が示され ているため, 紙幅上の都合で割愛する ${ }^{14)}$. 同表で明 らかなように, いずれの栽培形態においても, 栽培 規模の大きい農家層ほど環境保全型農業への取組割 合が高い。「無農薬」「無化学肥料」栽培に取り組ん でいる農家は，都府県平均で $1 \%$ 程度であるが，規 模が大きくなるにつれて取組農家の割合が安定的に 上昇し， 10 ha 以上層になると，それぞれ $6 \% ， 8 \%$ を超える。「減農薬」「減化学肥料」栽培においても 同様の傾向であり, 15 ha 以上層で取組農家は 5 割 の大台に到達したことが注目されるべきことであ る.

また，紙幅制約のため図表は省略するが，主業農 家, 後継者が比較的多く確保されている農家 (65 歳未満専従者がいる農家, 同居後継者（45 歳未満） が「主として農業」に従事する農家)，農業経営基 盤強化促進法により経営計画の認定を受けた認定 農業者といった，農業経営の主たる担い手と言わ れる農家層の方が, 副業的農家や販売農家平均よ りも環境保全型農業への取組割合が高いことも確 
表 5. 作付規模別環境保全型農業への取組水準：販売目的の米作農家

単位 : 戸, \%

\begin{tabular}{ccccccc}
\hline \hline \multirow{2}{*}{ 規模階層分類 } & 販売目的米作農家総数 & \multicolumn{5}{c}{ 取組農家対販売農家数\% } \\
\cline { 3 - 7 } & & 取組農家平均 & 無農薬 & 無化学肥料 & 減農薬 & 減化学肥料 \\
\hline 都府県平均 & $1,718,169$ & 21.5 & 1.0 & 1.2 & 15.3 & 14.1 \\
0.5 ha 未満 & 822,889 & 18.7 & 1.1 & 1.1 & 13.4 & 12.6 \\
$0.5 \sim 1.0$ & 509,676 & 21.4 & 1.0 & 1.1 & 15.5 & 14.2 \\
$1.0 \sim 2.0$ & 272,201 & 24.6 & 0.9 & 1.3 & 17.4 & 15.7 \\
$2.0 \sim 3.0$ & 67,952 & 29.8 & 1.0 & 1.8 & 20.3 & 18.2 \\
$3.0 \sim 5.0$ & 32,457 & 37.9 & 1.7 & 2.5 & 25.2 & 22.6 \\
$5.0 \sim 10.0$ & 10,771 & 47.4 & 2.6 & 4.1 & 32.5 & 27.6 \\
$10.0 \sim 15.0$ & 1,609 & 64.2 & 6.8 & 9.3 & 45.7 & 38.8 \\
15.0 ha 以上 & 614 & 71.0 & 5.5 & 7.8 & 54.9 & 47.7 \\
\hline
\end{tabular}

註：1）「減農薬」とは農薬の投入回数は地域慣行の半分以下,「減化学肥料」とは化学肥料の窒素成分量施用量は地域慣 行の半分以下を指す

2） 2000 年農業センサスにより作成.

認されている ${ }^{15)}$ ，環境保全型農業への取組はすべ ての経営層において見られるようになったが, 経 営規模が比較的大きく後継者が多数確保されてい る家族経営，家族法人経営，および農家以外の法 人・会社経営がその主な担い手となっている。 こ れらの経営体から抽出される共通項は言うまでも なく, 高い経営意欲と優れた効率感覚であろう，農 業を主業とし, 経営意欲が高く効率感覚に優れた 経営層を中心に環境保全型農業の担い手は多数形 成され, 経営意欲と効率感覚は, 農業経営だけで なく，環境保全型農業を前進させる上でも欠かせ ない要素となっているのである.

「生産性」と「環境」を調和した農業経営を生み 出した背景は言うまでもなく, 経費節約という農業 経営の一般的要請と, 食の安全, 安心や環境意識の 向上への対応という革新的農業経営の要請にある. 効率的で収益性の高い経営を実現するためには資材 の節約的利用が必要不可欠であり, 時代の要請を反 映した食と農の動きにも機敏に対応して行かねばな らないからである，停漫を回避し，発展を目指す農 業経営の必然的な動きではあるが, ここに示した諸 証拠は，理論的，実践的にも重要な意味を持ってい ると思われる。

まず,「生産性」か「環境」かの発想はもうナン センスである，という点である，効率的で生産性の 高い経営ほど, 環境への負荷が相対的に少なく, 環 境保全型農業への取組においても卓越した優位性を
示しているからである.「生産性」と「環境」は二 者択一の対立コンセプトと行動規範ではなく, 健全 な「食」と「農」を営んでゆく上でどちらも欠かせ ない補完的な存在であることが明らかである. 現場 では,「環境」と「効率」を統合した形の農業経営 が形成されつつあるが、こうした望ましい動きを発 展させ，環境保全型農業への移行を確実に進めてい くためにも，「生産性」か「環境」かの二者択一的 な発想と決別し, 両者を統合した理論視座と行動規 範の確立を図ら㸚ばならない.

このように考えれば, 農業環境問題への取組と農 業経済学問分野との接点を見出すこともできる，生 産性, 効率性は, 経済理論の基本的なコンセプトで あり，それに対する否定は，経済理論を環境問題の 領域から排除し，農業環境問題の解決に向けた学問 的探求が農業経済理論と違った学問体系から出発し なければならなくなることを意味する。しかし上述 したように, 生産性と環境は二者択一の対立コンセ プトと行動規範ではなく, 21 世紀に相応しい食と農 の形を創っていく上でどちらも欠かせない存在であ るということになれば, 新しい食と農の形づくりに 農業経済理論は重大な責務を背負うことになる。経 営経済問題と環境問題へ同時に対処していくことで 農業経済関連学問領域は, 重厚な理論蓄積を活かし ながら新たな発展期を迎える。

生産性, 効率性追求が環境保全と矛盾しないこと は，実践的にも重要な意味を持っている，いま，農 
業生産や農林行政の現場では, 激しさを増す国際競 争への対応や財政資源の傾斜的配分による構造改革 の推進が盛んに強調される一方, 前述したような 偏った生産性認識の下で効率改善, 生産性向上を主 張する自信が摇らいでいる. 生産性, 効率性の悪い 経営こそ, 同一単位の富を創出するためにより多く の資源を消耗し, 環境への負荷を増大させる可能性 があり，したがって，環境保全を図るためにも資源 の生産性, 効率性が追求されるべきとの認識は明確 にするべきであろう。こうした認識の明確化は, 農 林行政の取組をはじめ, 収量安定や収益向上に向け て懸命な経営努力を続けている有機認証農家, エコ ファーマーにも勇気を与えるものとなる ${ }^{16)}$.

これまでに, 農業環境問題には環境政策で, 経営, 構造問題には経営, 構造政策で対応してきた. 効率 的で生産性の高い経営ほど環境への負荷が相対的に 少なく, 環境保全型農業への取組においても優位に 立っていることが明確になったことで,「経営」「構 造」「環境」を統合した三位一体の政策展開が必要 不可欠となる. 農業政策の革新が求められる.

\section{5. 健全な生産性基準の確立に向けて}

生産性, 効率性追求で環境への負荷を増大させた 証拠は, 過去も今もなかった. 生産性, 効率性追求 が悪かったのでなく, 労働生産性を物差とする省力 化追求農法に偏重したことが問題である. より正確 に言うならば, 労働生産性追求自体も悪かったので なく, 物的資源のコスト勘定を無視し, 農薬や化学 肥料の過剰投入に象徵される化学農法でその向上を 図ったところに問題の本質があった ${ }^{17)}$. 労働生産性 本位の認識の下で物的資源の生産 (効率) 性追求が 不充分だったことこそ, 環境への負荷を増大させる 結果となったのである.

農林水産業のもつ自然循環機能を発揮し, 持続可 能な生産基盤と快啇な農村空間を形成していくため 環境保全を重視する農林漁業へ移行しなければなら ない一方, WTO や自由貿易協定 (FTA) 締結等の 交渉に打いて農業分野の譲歩が余儀なくされ, 国際 競争への対応が迫られる今日では ${ }^{18)}$, 環境保全と 収益向上を両立させる手段として生産性, 効率性追 求の大義名分を取り戻すべきである.すべての資源 の有効利用を視野に入れた健全な生産性追求で, 農 産物の資源コス卜削減と安全性向上, 生物多様性と
自然環境の保全を同時に図り, 環境便益も経済便益 も社会便益も提供できる農のシステムを構築すべき である.

そのためには，2 つのことがまず必要である，1 つは, 物的労働生産性本位の生産性認識を改めるこ とである. 偏った生産性認識は理論的にも実践的に も有害である. 労働の生産性は部分的要素の生産性 の 1 つとして認識し, 農業に打ける生産性追求は労 働だけでなく物的要素の生産性を含めた健全な経営 行動であることを明確にすべきであろう，労働のみ に偏った生産性認識の是正は, 健全な生産性, 効率 認識を醇成するための前提となる.

いま 1 つは，健全な生産性基準を確立すること である. 労働も物的資源も包含した生産性尺度と して, 総合生産性とも全要素生産性（Total Factor Productivity, 略称 TFP) とも呼ばれるものがある. 1960 年代に確立した範疇で, 国内でもかなりの研 究蓄積がある ${ }^{19)}$. 欧米では, 早い段階でこれを官 庁統計に導入し, 経済活動の評価に活されている が20), 国内では, 基本的に理論分析の道具のみと して使われている. 労働生産性本位の生産性認識 から全要素生産性認識に変えていくには, TFPを 農林統計体系に取り入れ, 経営経済活動のパフォー マンスや政策遂行効果を評価する 1 つの尺度にす べきである。その意味では,「農業の生産性」の向 上を労働生産性の向上に置き換えたこれまでの政 策評価手法を見直すべきであろう。健全な生産性 基準の確立は偏った生産性認識の是正を促し, 健 全な食と農の形成に寄与するものとなる.

註 1) 経済学教科書において生産性と効率性は同一概念では ないが, マスコミや公文書等で同等に使われる場合が 多い。本稿では概念的な説明を省き, 必要に応じて使 い分ける.

2）農林水産省が昨年公表した『農林水産環境政策の基本 方針』において環境保全を重視する農林漁業への移行 を宣言している.

3）これについては, 小田原〔4]をご一読されたい.

4）梶井 [6] (pp. 67-68), [7] (pp. 313-314)を参照されたい.

5）同大会では，「有機農業技術は，はたして「生産性」(多 収や低コストや快適さ) を求めなければならないのか」 のセッションが設定され, 有機農業運動を進める上で 生産性追求の妥当性についての検討が必要であるとの 課題を提起している（文献〔9]）.

6) 2004 年 3 月 7 日付『日本農業新聞』記事（1 面）を参 
照されたい.

7)「農家経済調査」を用いて算出した数量指数であり, 全 国集計データで算出される数量指数の変化に必ずしも 一致しないと思われるが, 産出との整合性をもつ詳細 な費用データが含まれているため, 生産性変化の考察 に適していると考える. なお，以下に示すように，同 表の計算結果は集計データを用いた速水の計算結果と 大差がなく、どのデータを使ってもこの論議に影響す るほどのものにならないと思われる。

8）速水佑次郎 [10]（p. 12，1-4 表）を参照されたい.

9）佐伯尚美 [8]（p. 80）を参照されたい.

10）『農業白書付属統計表 平成 7 年度』（農林統計協会, p. 146）を参照されたい.

11）（1）式のように生産の技術構造を一次同次関数 $\mathrm{Y}=(\mathrm{L}$, $\mathrm{K}, \mathrm{A})$ と想定し，オイラー定理を用いて展開すれば $\mathrm{Y}=(\partial \mathrm{Y} / \partial \mathrm{L}) \cdot \mathrm{L}+(\partial \mathrm{Y} / \partial \mathrm{K}) \cdot \mathrm{K}+(\partial \mathrm{Y} / \partial \mathrm{A}) \cdot \mathrm{A}$ となる. 競争的 帰属の条件の下では要素の限界生産物がその実質価格 に等しくなるため, J.B. Clark と P.H. Wicksteed の生産 物完全分配定理（product exhaustion theorem）が得ら れる (文献〔2〕参照).

12）農薬，肥料等の使用は必ず環境に負荷を与えるとは限 らない．農薬や肥料の中で環境に負荷を与えないもの があるし，同一の農薬や肥料を使っても農法や使い方 によって環境に負荷を与えない可能性もある. ここで 「環境関連資材費」の表現を使ったのが, 上に引用した 食料・農業・農村白書のニュアンスに沿ったものであ り，吟味の余地がある。

13）「環境保全型農業」とは, 農林水産省の統計定義に沿っ たものであり，畜産部門が含まれていない，畜産経営 の粪尿污染と処理コストを含めた場合の検討は今後の 課題となる.

14）〜15）詳細は，小論 [14〕を参照されたい.

16）収益向上に向けた取組農家の経営努力事例について, 小論〔13]を参照されたい.

17）このことは必ずしも農家が利益を無視して行動してい ることを意味しない. 労働や他の投入財に比べて農薬, 化学肥料の相対価格が低下すれば,「農薬・化学肥料使 用, 他要素節約」の投入行動が誘発され, 技術的意味 に打いての農薬, 化学肥料過剰投入をもたらすことに なる. この点についての分析は, 小論 [12]を参照さ れたい.

18）WTO 加盟をめぐる中国と米国の農業交渉において中 国側の大幅な譲歩で決着したこと, 日墨FTA 交渉にお いて日本側が一定の譲歩案を提示したことが好例であ る.

19）詳細は省略するが, 1994 年までは加古 [5]のレビュー, その後の研究として小論〔11], およびKuroda \& Ruziruddin Abdullah 〔3〕を参照されたい.

20）例えば，英国の Central Statistical Office は, 1969 年に
1949 ～ 67 年英国農業の全要素生産性（TFP）指数を公 表し, 1985 年以降では “Farm Incomes” 統計指標に取 り入れている. EC (現 EU) 委員会は, 1990 年代初期 から域内各国の農業TFP指数を作成するようにしてい る. 米国農務省 (USDA) も, 1980 年代から米国, 力 ナダ，英国，フランス，ドイツ，オランダ諸国の農業 TFP 指数の作成に着手した (Thirtle, C. and P. Bottomley [1]).

\section{引用文献}

〔1] Thirtle, C. and P. Bottomley, "Total Factor Productivity in UK agriculture, 1967-90." Journal of Agricultural Economics, 43(3), 1992, pp. 381-400.

[2] Johnson, H.G., The Theory of Income Distribution, London: Glay-Mills, 1973.

[3] Kuroda. Yoshimi and Ruziruddin Abdullah, "Impacts of Set-Aside and R\&E Policies on Agricultural Productivity in Japan, 1965-97", The Japanese Journal of Rural Economics, 5, 2003, pp. 12-34.

〔4〕小田原高昭「農業革命の経済学一『梶井功著作集』を 読む一」『農業経済研究』第 61 巻第 2 号 (1989 年), pp. 89-95.

〔5]加古敏之「第 5 章 農業の生産性」荏開津典生・中安 定子編『農業経済の動向と展望』, 富民協会, 1996 年, pp. $92-105$.

〔6]梶井 功編『農業の基本法制 : 問題点と改正試論』, 家 の光協会, 1992 年.

〔7〕梶井 功『国際化農政期の農業問題』, 家の光協会, 1997 年.

〔8〕佐伯尚美著『農業経済学講義』, 東京大学出版会, 1989 年.

〔9]日本有機農業学会『第 4 回（2004 年度）日本有機農業 学会大会資料』.

〔10〕速水佑次郎『農業経済論』，岩波書店，1986 年.

〔11〕胡柏「日本農業の全要素生産性変動の性格と要 因」『農林業問題研究』第 31 巻第 3 号 (1995 年), pp. $11 \sim 19$.

[12]胡柏「減農薬・減化学肥料農業の成立条件」『農業 環境政策の形成原理と形成条件に関する総合的研究: 平 成 9 年度 平成 10 年度科学研究費助成金（基盤研究 B

（2））研究成果報告書』（研究代表者 横川 洋），1999 年, pp. 75-87.

〔13〕胡柏「環境保全型稲作の収益形成力と形成条件分 析」『農業経済研究』第 73 巻第 1 号 (2001 年), pp. 1-15.

〔14〕胡柏「環境保全型農業の担い手構造」『農林統計調 查』第 54 巻第 1 号 (2004 年), pp. 12-20.

（受理日：2004 年 12 月 13 日） 